\title{
Preliminary characteristics of fungistatic metabolites produced by Paenibacillus sp.
}

\author{
Wstępna charakterystyka fungistatycznych metabolitów \\ wytwarzanych przez Paenibacillus sp.
}

\author{
Romuald Gwiazdowski ${ }^{1}$, Daniela Gwiazdowska ${ }^{2}$, Krzysztof Juś $^{2}$, \\ Amelia Bednarek-Bartsch ${ }^{1}$, Beata Danielewicz ${ }^{1}$
}

\section{Summary}

The aim of presented research was an evaluation of fungistatic activity of two strains of Paenibacillus species including preliminary characteristics of metabolites responsible for antagonism. The tested strains inhibited growth of all fungi used as indicators however belonging to Microdochium and Septoria genera were more sensitive than Fusarium. It was observed that larger amount of Paenibacillus sp. added to culture caused usually stronger inhibition of fungal growth and antifungal effect was comparable for both strains. Enzymatic hydrolysis revealed completely lost of antagonistic activity, what indicates that fungistatic metabolites are proteins.

Key words: fungistatic activity, preliminary characteristics, protein

\section{Streszczenie}

Celem pracy była ocena fungistatycznej aktywności dwóch szczepów bakterii z rodzaju Paenibacillus z uwzględnieniem wstępnej charakterystyki metabolitów, odpowiedzialnych za antagonizm. Badane szczepy hamowały rozwój wszystkich grzybów wskaźnikowych, jednak większą wrażliwość wykazały grzyby rodzaju Microdochium i Septoria niż Fusarium. Większy dodatek hodowli Paenibacillus sp. powodował zwykle silniejsze zahamowanie wzrostu grzybów, przy czym oddziaływanie obu szczepów było podobne. Hydroliza enzymatyczna białek spowodowała całkowity zanik aktywności antagonistycznej, co wskazuje że fungistatyczne metabolity są białkami.

Słowa kluczowe: właściwości fungistatyczne, wstępna charakterystyka, białko

\footnotetext{
${ }^{1}$ Instytut Ochrony Roślin - Państwowy Instytut Badawczy

Zakład Badania Środków Ochrony Roślin

Władysława Węgorka 20, 60-318 Poznań

R.Gwiazdowski@iorpib.poznan.pl

${ }^{2}$ Uniwersytet Ekonomiczny w Poznaniu

Wydział Towaroznawstwa

Katedra Przyrodniczych Podstaw Jakości

Niepodległości 10, 61-875 Poznań
} 


\section{Wstęp / Introduction}

Rodzaj Paenibacillus został wyodrębniony, jako osobna filogenetycznie grupa tlenowych i względnie beztlenowych przetrwalnikujących laseczek, na podstawie analizy 16sRNA (Ash i wsp. 1993; Shida i wsp. 1997). Obecnie do rodzaju tego zalicza się 24 gatunki (Shida i wsp. 1997). Bakterie rodzaju Paenibacillus są szeroko rozpowszechnione w środowisku. Ich obecność wykryto między innymi w glebie (Axelrood i wsp. 2002; Garbeva i wsp. 2003), wodzie (Ross i wsp. 2001), ryzosferze (Berge i wsp. 2002; von der Weid i wsp. 2002) czy w tkankach roślin (Shishido i wsp. 1999; Garbeva i wsp. 2001).

Dane literaturowe wskazują, że niektóre gatunki bakterii rodzaju Paenibacillus, m.in. P. polymyxa czy $P$. thiaminolyticus mają zdolność do wytwarzania substancji o charakterze antybakteryjnym, takich jak polimyksyna czy bacifelacyna (Slepecky i Hemphill 1991). Kilka gatunków jest również znanych $\mathrm{z}$ produkcji enzymów degradujących naturalne polimery, m.in. chondroitynę, kurdlan czy chitynę (Nakamura 1987; Kanzawa i wsp. 1995). W ostatnich latach pojawia się coraz więcej doniesień dotyczących wytwarzania przez te bakterie substancji antygrzybowych. Najlepiej poznanym gatunkiem wykazującym właściwości fungistatyczne jest $P$. polymyxa, powszechnie występujący w glebie i w ryzosferze (Timmusk i Wagner 1999). Oprócz związków antybakteryjnych bakterie tego gatunku wytwarzają fuzarycydyny $o$ silnych właściwościach antygrzybowych w stosunku do takich grzybów, jak: Fusarium oxysporum, Aspergillus niger, Aspergillus oryzae, Penicillium thomii (Kajimura i Kaneda 1996, 1997) czy Leptosphaeria maculans (Beatty i Jensen 2002). Chung (1997) opisał chitynolityczny szczep bakterii, wyizolowany z kompostu, który wykazywał aktywność fungistatyczną wobec grzybów Rhizoctonia solani, Fusarium oxysporum, Colletotrichum lagenarium, Sclerotinia sclerotiorum i Botrytis cinerea. Na podstawie charakterystyki fenotypowej oraz analizy molekularnej szczep ten sklasyfikowano jako Paenibacillus koreensis sp. nov. (Lee i wsp. 2008) wykazali antagonistyczne właściwości szczepu $P$. lentimorbis WJ5, wyizolowanego $\mathrm{z}$ gleby wobec różnych patogenów roślin.

Niektóre szczepy bakterii Paenibacillus są zaliczane do PGPR (Plant Growth - Promoting Rhizobacteria), czyli do bakterii pozytywnie wpływających na rośliny uprawne (Timmusk i Wagner 1999; Cheong i wsp. 2005). Oprócz wspomnianych wcześniej właściwości antagonistycznych wobec patogenów roślinnych, bakterie Paenibacillus mogą być wykorzystywane w rolnictwie do poprawy kondycji roślin. Bakterie te występują na różnych częściach roślin na zasadzie symbiozy, dzięki czemu dochodzi do stymulacji wzrostu roślin oraz zwiększenia ich odporności na różne czynniki zewnętrze. Stymulacja wzrostu roślin przez te bakterie odbywa się poprzez wytwarzanie fitohormonów, wspomaganie pobierania związków mineralnych przez rośliny, ograniczanie rozwoju patogenów (wytwarzanie związków przeciwgrzybiczych, produkcja antybiotyków, ograniczanie dostępu patogenom do pożywienia) (Kalitkiewicz i Kępczyńska 2008).
Właściwości fungistatyczne bakterii rodzaju Paenibacillus są mało poznane, jednak dotychczasowa wiedza pozwala sądzić, że mogą stanowić one czynnik biologicznej ochrony roślin przed patogenami i być wartościową alternatywą dla środków chemicznych. W niniejszej pracy przedstawiono aktywność fungistatyczną dwóch gatunków Paenibacillus sp. z uwzględnieniem wstępnej charakterystyki wytwarzanych przez nie substancji antygrzybowych.

\section{Materiały i metody / Materials and methods}

\section{Material badawczy}

W badaniach zastosowano dwa szczepy bakterii testowych: Paenibacillus alvei PCM 481 i P. macerans PCM 1399 - szczepy pochodziły z kolekcji Instytutu Immunologii i Terapii Doświadczalnej Polskiej Akademii Nauk we Wrocławiu. Bakterie hodowano na bulionie odżywczym przez 48 godzin w temperaturze $30^{\circ} \mathrm{C}$. W zależności od doświadczenia stosowano hodowle z komórkami oraz supernatanty otrzymane po odwirowaniu hodowli (6000 rpm/min, 15 minut).

\section{Mikroorganizmy wskaźnikowe}

Jako mikroorganizmy wskaźnikowe zastosowano grzyby rodzajów: Fusarium (F. avenaceum, F. oxysporum, $F$. culmorum, $F$. graminearum, $F$. equiseti, $F$. langsetiae), Microdochium nivale oraz Septoria tritici i $S$. nodorum. Grzyby pochodziły z kolekcji Zakładu Badania Środków Ochrony Roślin Instytutu Ochrony Roślin - Państwowego Instytutu Badawczego w Poznaniu.

\section{Ocena aktywności fungistatycznej metodą płytkową}

Oznaczenie aktywności fungistatycznej przeprowadzono metodą płytkową na podłożu PDA (Potato Dextrose Agar). Do płynnej pożywki dodawano hodowle bakterii o gęstości komórek $10^{10} \mathrm{jtk} / \mathrm{ml}$ w ilości 5 i $10 \%$ lub supernatanty otrzymane $\mathrm{z}$ hodowli w ilości 1 i 5\%, a po zestaleniu pożywki na centralnej części płytki umieszczano krążek wycięty z obwodu kultury grzyba. Po osiagnnięciu brzegu płytki przez próby kontrolne określono stopień zahamowania wzrostu.

\section{Hydroliza enzymatyczna}

Roztwory enzymów: proteazy i proteinazy $\mathrm{K}$ przygotowywano $\mathrm{w}$ buforze fosforanowym i dodawano do supernatantów tak, by ostateczne stężenie wynosiło $0,5 \mathrm{mg} / \mathrm{ml}$. Następnie prowadzono hydrolizę białek przez 2 godziny $\mathrm{w} 37^{\circ} \mathrm{C}$. Po zakończeniu hydrolizy, enzymy inaktywowano poprzez ogrzewanie przez 3 minuty w temperaturze $80^{\circ} \mathrm{C}$, a następnie oznaczano aktywność fungistatyczną supernatantów metodą opisaną wcześniej.

\section{Analiza statystyczna}

Wyniki opracowano statystycznie testem Student-Newman-Keuls przy poziomie istotności $\mathrm{p}=0,05$. 


\section{Wyniki i dyskusja / Results and discussion}

W pierwszej części doświadczeń oceniono oddziaływanie badanych szczepów Paenibacillus sp. na wzrost wybranych grzybów rodzajów Microdochium, Septoria i Fusarium (tab. 1). Wyniki doświadczeń wykazały, że obydwa szczepy bakterii hamowały rozwój testowanych grzybów, jednak większą wrażliwością charakteryzowały się rodzaje Microdochium i Septoria. W zależności od ilości dodanej do podłoża hodowli bakterii, stopień zahamowania grzybni wynosił od 33 do 88\%. Bardzo duże zróżnicowanie stopnia hamowania grzybni obserwowano w przypadku grzybów rodzaju Fusarium. W zależności od gatunku grzyba, procent zahamowania wynosił od 8 do $79 \%$ w przypadku zastosowania 5\% dodatku hodowli bakterii oraz od 26 do $87 \%$ w przypadku zastosowania dodatku $10 \%$. Porównując siłę oddziaływania testowanych szczepów bakterii można zauważyć podobny stopień zahamowania poszczególnych grzybów, co sugeruje że większe znaczenie w tym wypadku miał gatunek grzyba i jego wrażliwość na metabolity wytwarzane przez Paenibacillus sp. Podobnie zróżnicowane oddziaływanie różnych gatunków bakterii należących do rodzaju Paenibacillus obserwowali inni autorzy (Kajimura i Kaneda 1996, 1997; Chung 1997; Beatty i Jensen 2002).

Do drugiego etapu badań, mającego na celu wstępne określenie charakteru antagonistycznych metabolitów, wybrano szczep Paenibacillus alvei PCM 481. W dotychczasowych badaniach do oceny aktywności antygrzybowej wykorzystywano hodowle bakterii, tym razem badaniu został poddany supernatant. Jak wynika z tabeli 2 ., supernatant wykazał silne oddziaływanie wobec grzybów rodzaju Fusarium, co świadczy o tym, iż wytwarzana przez $P$. alvei substancja należy do metabolitów wydzielanych zewnątrzkomórkowo. Biorąc pod uwagę fakt, iż wiele metabolitów przeciwdrobnoustrojowych ma charakter białkowy, supernatanty poddano hydrolizie enzymatycznej z udziałem proteazy i proteinazy K.

Rezultaty przeprowadzonego doświadczenia wykazały, że supernatanty poddane działaniu enzymów proteolitycznych utraciły właściwości fungistyczne (tab. 2, rys. 1). Dodatek proteazy i proteinazy $\mathrm{K}$ do supernatatanu $\mathrm{z}$ hodowli $P$. alvei zniwelował działanie antagonistyczne wobec grzybów, czego efektem był wzrost grzybni $\mathrm{w}$ takim samym tempie, jak w próbie kontrolnej. Wyniki pozwalają stwierdzić, że substancja produkowana przez bakterie $P$. alvei, nadająca im właściwości fungistatyczne, jest substancją o charakterze białkowym.

Uzyskane wyniki znajduja potwierdzenie w danych literaturowych. Przykładem antygrzybowych metabolitów o białkowym charakterze są m.in. fuzarycydyny, wytwarzane przez Paenibacillus sp. Różne analogi fuzarycydyn wyizolowano $\mathrm{z}$ hodowli $P$. polymyxa, w tym LI-F03, LIF04,LI-F05, LI-F06, LI-F07 i LI-F08 (Kurusu i wsp. 1987; Kuroda i wsp. 2001), jak również fuzarycydyny A-D (Kajimura i Kaneda 1996, 1997). Selim i wsp. (2005) wyizolowali i scharakteryzowali antagonistyczne peptydy wytwarzane przez Paenibacillus sp. pochodzace z mikoryzosfery sorga, a Lee i wsp. (2008) potwierdzili białkowy charakter antygrzybowego metabolitu produkowanego przez P. lentimorbis WJ5.

Antygrzybowe, białkowe metabolity budzą coraz większe zainteresowanie w biologicznej ochronie roślin przed patogenami, szczególnie w obliczu tendencji do poszukiwania alternatywy dla stosowania syntetyzowanych, chemicznych środków ochrony roślin.

Tabela 1. Fungistatyczna aktywność $P$. alvei PCM 481 i $P$. macerans PCM 1399 wobec wybranych grzybów patogenicznych Table 1. Fungistatic activity of $P$. alvei PCM 481 and P. macerans PCM 1399 against chosen pathogenic fungi

\begin{tabular}{l|c|c|c|c}
\hline \multirow{2}{*}{$\begin{array}{c}\text { Gatunek grzyba } \\
\text { Fungal species }\end{array}$} & \multicolumn{2}{c}{$\begin{array}{c}\text { Procent zahamowania wzrostu } \\
\text { przez P. alvei PCM 481 } \\
\text { Percent of growth inhibition } \\
\text { by P. alvei PCM 481 }\end{array}$} & $\begin{array}{c}\text { Procent zahamowania wzrostu } \\
\text { przez P. macerans PCM 1399 } \\
\text { Percent of growth inhibition } \\
\text { by P. macerans PCM 1399 }\end{array}$ \\
\cline { 2 - 5 } & $\begin{array}{c}5 \% \text { dodatek hodowli } \\
5 \% \text { additive of culture }\end{array}$ & $\begin{array}{c}10 \% \text { dodatek hodowli } \\
10 \% \text { additive of culture }\end{array}$ & $\begin{array}{c}5 \% \text { dodatek hodowli } \\
5 \% \text { additive of culture }\end{array}$ & $\begin{array}{c}10 \% \text { dodatek hodowli } \\
10 \% \text { additive of culture }\end{array}$ \\
\hline Kontrola - Control & $0 \mathrm{a}$ & $0 \mathrm{a}$ & $0 \mathrm{a}$ & $0 \mathrm{a}$ \\
\hline Microdochium nivale & $81 \mathrm{c}$ & $88 \mathrm{c}$ & $70 \mathrm{bc}$ & $87 \mathrm{c}$ \\
\hline Septoria tritici & $85 \mathrm{c}$ & $51 \mathrm{bc}$ & $80 \mathrm{c}$ & $51 \mathrm{c}$ \\
\hline S. nodorum & $61 \mathrm{c}$ & - & $33 \mathrm{~b}$ & - \\
\hline Fusarium avenaceum 2010 & $52 \mathrm{~b}$ & $79 \mathrm{c}$ & $50 \mathrm{~b}$ & $78 \mathrm{c}$ \\
\hline F. avenaceum 1592 & $69 \mathrm{c}$ & $78 \mathrm{c}$ & $65 \mathrm{c}$ & $75 \mathrm{c}$ \\
\hline F. culmorum F01 & $23 \mathrm{~b}$ & $65 \mathrm{c}$ & $34 \mathrm{~b}$ & $72 \mathrm{c}$ \\
\hline F. equiseti F31 & $22 \mathrm{~b}$ & $72 \mathrm{c}$ & $22 \mathrm{~b}$ & $70 \mathrm{c}$ \\
\hline F. graminearum F11 & 0 & $38 \mathrm{~b}$ & 0 & $53 \mathrm{c}$ \\
\hline F. langsetiae & $79 \mathrm{c}$ & - & $70 \mathrm{c}$ & - \\
\hline F. oxysporum F41 & $11 \mathrm{~b}$ & $30 \mathrm{~b}$ & $8 \mathrm{~b}$ & $26 \mathrm{~b}$ \\
\hline
\end{tabular}

$\mathrm{a}, \mathrm{b}, \mathrm{c}-$ różnice istotne przy $\mathrm{p}<0,5$ - significantly different at $\mathrm{p}<0.5$ 
Tabela 2. Wpływ enzymów proteolitycznych na aktywność fungistatyczną supernatantów otrzymanych z hodowli $P$. alvei PCM 481 Table 2. The influence of proteolytic enzymes on the fungistatic activity of supernatants obtained from $P$. alvei PCM 481culture

\begin{tabular}{|c|c|c|}
\hline \multirow[t]{2}{*}{ Badana frakcja } & \multicolumn{2}{|c|}{$\begin{array}{l}\text { Procent zahamowania grzybni przez } P \text {. alvei PCM } 481 \\
\text { Percent of growth inhibition by } P \text {. alvei PCM } 481\end{array}$} \\
\hline & F. avenaceum 1592 & F. culmorum F01 \\
\hline Kontrola-Control & $0 \mathrm{a}$ & $0 \mathrm{a}$ \\
\hline $\begin{array}{l}1 \% \text { dodatek supernatantu } \\
1 \% \text { addition of supernatant }\end{array}$ & $61 \mathrm{~b}$ & $17 \mathrm{~b}$ \\
\hline $\begin{array}{l}5 \% \text { dodatek supernatantu } \\
5 \% \text { addition of supernatant }\end{array}$ & $65 \mathrm{~b}$ & $20 \mathrm{~b}$ \\
\hline $\begin{array}{l}1 \% \text { dodatek supernatantu po hydrolizie } \\
\text { enzymatycznej z proteazą } \\
1 \% \text { addition of supernatant after enzymatic } \\
\text { hydrolysis with protease }\end{array}$ & $0 \mathrm{a}$ & $0 \mathrm{a}$ \\
\hline $\begin{array}{l}5 \% \text { dodatek supernatantu po hydrolizie } \\
\text { enzymatycznej z proteazą } \\
5 \% \text { addition of supernatant after enzymatic } \\
\text { hydrolysis with protease }\end{array}$ & $0 \mathrm{a}$ & $0 \mathrm{a}$ \\
\hline $\begin{array}{l}1 \% \text { dodatek supernatantu po hydrolizie } \\
\text { enzymatycznej z proteinazą } \mathrm{K} \\
1 \% \text { addition of supernatant after enzymatic } \\
\text { hydrolysis with proteinase } \mathrm{K}\end{array}$ & $0 \mathrm{a}$ & $0 \mathrm{a}$ \\
\hline $\begin{array}{l}5 \% \text { dodatek supernatantu po hydrolizie } \\
\text { enzymatycznej z proteinazą } \mathrm{K} \\
5 \% \text { addition of supernatant after enzymatic } \\
\text { hydrolysis with proteinase } \mathrm{K}\end{array}$ & $0 \mathrm{a}$ & $0 \mathrm{a}$ \\
\hline
\end{tabular}

$\mathrm{a}, \mathrm{b}$ - różnice istotne przy $\mathrm{p}<0,5$ - significantly different at $\mathrm{p}<0.5$

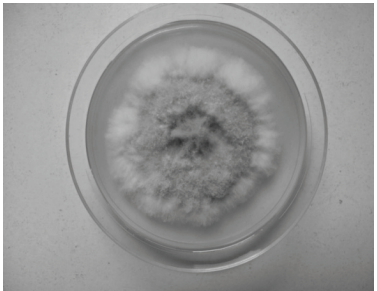

A

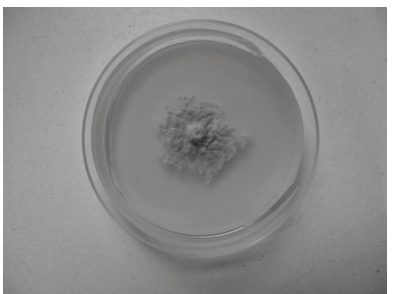

B

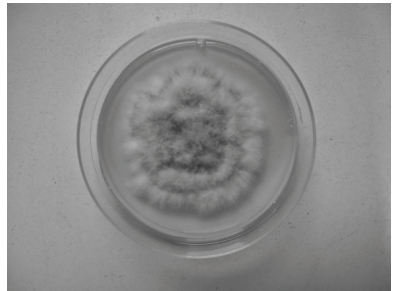

C

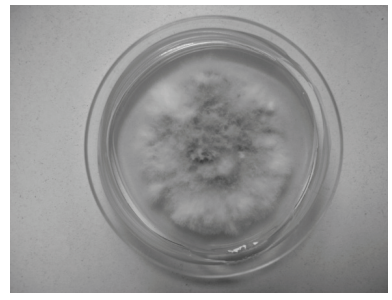

$\mathrm{D}$

A - bez dodatku supernatantu z hodowli $P$. alvei 481 (kontrola)

B - z dodatkiem 5\%supernatantu z hodowli $P$. alvei 481

$\mathrm{C}-\mathrm{z}$ dodatkiem $5 \%$ supernatantu z hodowli $P$. alvei 481 po hydrolizie enzymatycznej proteaza

D - z dodatkiem $5 \%$ supernatantu z hodowli $P$. alvei 481 po hydrolizie enzymatycznej proteinaza $\mathrm{K}$

A - without addition of supernatant from $P$. alvei PCM 481 culture (control)

B - with addition of $5 \%$ supernatant from $P$. alvei PCM 481 culture

C - with addition of $5 \%$ supernatant from $P$. alvei PCM 481 culture after enzymatic hydrolysis with protease

$\mathrm{D}$ - with addition of $5 \%$ supernatant from $P$. alvei PCM 481 culture after enzymatic hydrolysis with proteinase $\mathrm{K}$

Rys. 1. Kultury $F$. avenaceum 1952 na pożywce PDA

Fig. 1. Cultures of $F$. avenaceum 1952 on PDA medium

\section{Wnioski / Conclusions}

Na podstawie przeprowadzonych doświadczeń można wysunąć następujące wnioski:

1. Bakterie Paenibacillus alvei PCM 481 i P. macerans PCM 1399 wykazują fungistatyczne oddziaływanie wobec grzybów rodzajów Microdochium, Fusarium i Septoria.
2. Supernatanty $\mathrm{z}$ hodowli $P$. alvei wykazują oddziaływanie antagonistyczne wobec grzybów $F$. avenaceum i F. culmorum, co dowodzi, iż wytwarzane przez nie substancje należą do metabolitów zewnątrzkomórkowych.

3. Supernatanty poddane działaniu enzymów proteolitycznych (proteazy i proteinazy K) traciły całkowicie aktywność, co sugeruje, że substancja antagonistyczna ma charakter białkowy. 


\section{Literatura / References}

Ash C., Priest F.G., Collins M.D. 1993. Molecular identifcation of rRNA group 3 bacilli (Ash, Farrow, Wallbanks and Collins) using a PCR probe test. Proposal for the creation of a new genus Paenibacillus. Antonie Leeuwenhoek 64: 253-260.

Axelrood P.E., Chow M.L., Arnold C.S., Lu K., McDermott J.M., Davies J. 2002. Cultivation-dependent characterization of bacterial diversity from British Columbia forest soils subjected to disturbance. Can. J. Microbiol. 48: 643-654.

Beatty P.H., Jensen S.E. 2002. Paenibacillus polymyxa produces fusaricidin-type antifungal antibiotics active against Leptosphaeria maculans, the causative agent of blackleg disease of canola. Can. J. Microbiol. 48: 159-169.

Berge O., Guinebretiere M.H., Achouak W., Normand P., Heulin T. 2002. Paenibacillus graminis sp. nov. and Paenibacillus odorifer sp. nov., isolated from plant roots, soil and food. Int. Syst. Evolution. Microbiol. 52: 607-616.

Cheong H., Park S.Y., Ryu C.M., Kim J.H.F., Park S.H., Park C.S. 2005. Diversity of root-associated Paenibacillus spp. in winter crops from the southern part of Korea. J. Microbiol. Biotechnol. 15: 1286-1298.

Chung M.H. 1997. Biological control of Rhizoctonia dampingoff of radish by antagonistic bacteria with chitinolytic activity in commercial bed soils. MSc thesis, Gyeongsang National University, Chinju, Korea.

Garbeva P., van Overbeek L.S., van Vuurde J.W.L., van Elsas J.D. 2001. Analysis of endophytic bacterial communities of potato by planting and denaturing gradient gel electrophoresis (DGGE) of 16S rDNA based PCR fragments. Microbial Ecol. 41: $369-383$.

Garbeva P., van Veen J.A., van Elsas J.D. 2003. Predominant Bacillus spp. in agricultural soil under different management regimes detected via PCR-DGGE. Microbial Ecol. 45: 302-316.

Kajimura Y., Kaneda M. 1996. Fusaricidin A, a new depsipeptide antibiotic produced by Bacillus polymyxa KT-8. Taxonomy, fermentation, isolation, structure elucidation and biological activity. J. Antibiot. (Tokyo) 49: 129-135.

Kajimura Y., Kaneda M. 1997. Fusaricidins B, C, and D, new depsipeptide antibiotics produced by Bacillus polymyxa KT-8: isolation, structure elucidation and biological activity. J. Antibiot. (Tokyo) 50: 220-228.

Kalitkiewicz A., Kępczyńska E. 2008. Wykorzystanie ryzobakterii do stymulacji wzrostu roślin. Biotechnologia 81: 102-114.

Kanzawa Y., Harada A., Takeuchi A., Yokota A., Harada T. 1995. Bacillus curdlanolyticus sp. nov. and Bacillus kobensis sp. nov., which hydrolyze resistant curdlan. Int. J. Syst. Bacteriol. 45: 515-521.

Kuroda J., Fukai T., Nomura T. 2001. Collision-induced dissociation of ring-opened cyclic depsipeptides with a guanidino group by electrospray ionization/ion trap mass spectrometry. J. Mass Spectrom. 36: 30-37.

Kurusu K., Ohba K., Arai T., Fukushima K. 1987. New peptide antibiotics LI-F03, F04, F05, F07, and F08, produced by Bacillus polymyxa. I. Isolation and characterization. J. Antibiot. (Tokyo) 40: 1506-1514.

Lee Y.K., Senthilkumar M., Kim J.H., Swarnalakshmi K., Annapurna K. 2008. Purification and partial characterization of antifungal metabolite from Paenibacillus lentimorbus WJ5. World J. Microbiol. Biotechnol. 24: 3057-3062.

Nakamura L.K. 1987. Bacillus alginolyticus sp. nov. and Bacillus chondroitinus sp. nov., two alginate-degrading species. Int. J. Syst. Bacteriol. 37: 284-286.

Ross N., Villemur R., Marcandella E., Deschenes L. 2001. Assessment of changes in biodiversity when a community of ultramicrobacteria isolated from groundwater is stimulated to form a biofilm. Microbial Ecol. 42: 56-68.

Selim S., Negrel J., Govaerts C., Gianinazzi S., van Tuinen D. 2005. Isolation and partial characterization of antagonistic peptides produced by Paenibacillus sp. strain B2 isolated from the sorghum mycorrhizosphere. Appl. Environ. Microbiol. 71: 6501-6507.

Shida O., Takagi H., Kadowaki K., Nakamura L.K., Komagata K. 1997. Transfer of Bacillus alginolyticus, Bacillus chondroitinus, Bacillus curdlanolyticus, Bacillus lucanolyticus, Bacillus kobensis, and Bacillus thiaminolyticus to the genus Paenibacillus and emended description of the genus Paenibacillus. Int. J. Syst. Bacteriol. 47: 289-298.

Shishido M., Breuil C., Chanway C.P. 1999. Endophytic colonization of spruce by plant growth-promoting rhizobacteria. FEMS Microbiol. Ecol. 29: 191-196.

Slepecky R.A., Hemphill H.E. 1991. The genus Bacillus - nonmedical. p. 1663-1696. In: "The prokaryotes" (A. Balows, H.G. Trusper, M. Dworkin, W. Harder, K.H. Schleifer, eds). Springer, New York, 1992 pp.

Timmusk S., Wagner E.G.H. 1999. The plant-growth promoting rhizobacterium Paenibacillus polymyxa indu ces changes in Arabidopsis thaliana gene expression: A possibile connection between biotic and abiotic stress responses. Mol. Plant Microbiol. Interact. 2: 951-959.

von der Weid I., Duarte G.F., van Elsas J.D., Seldin L. 2002. Paenibacillus brasilensis sp. nov., a novel nitrogen-fixing species isolated from the maize rhizosphere in Brazil. Int. J. System. Evol. Microbiol. 52: 2147-2153. 